\title{
MENYOAL BANGUNAN ILMU PRODI PENDIDIKAN AGAMA ISLAM
}

\author{
Musyafa Ullah \\ Institut Agama Islam Jamiat Kheir \\ Jl. Kh. Mas Mansyur No.17, RT.10/RW.6, Kb. Kacang, Jakarta 10240 \\ Email: musyafa.ullah@gmail.com
}

\begin{abstract}
Questioning the Structure of the Science of Islamic Education Study Program. The issue of the integration of science in higher Islamic education institution, especially in Islamic Education study program has not been fully implemented yet. The lecture materials given to the PAI Study Program in addition to the religious sciences and general sciences, especially those related to psychology and teaching methodology. Hence, both of the sciences should be juxtaposed to produce qualified teacher candidates who are not only knowledgeable in Islamic materials but also know how to deliver such materials in the classroom. This study shows that the structure of the science of PAI is very solid ontologically, epistemologically, and axiologically, that it can be maintained as a structure of science.
\end{abstract}

Keywords: Islamic Education Study Program, ontology, epistemology, and axiology

Abstrak: Menyoal Bangunan Ilmu Prodi Pendidikan Agama Islam. Sampai saat ini, persoalan integrasi ilmu di lembaga pendidikan tinggi keagamaan Islam khususnya program studi Pendidikan Agama Islam belum tuntas dilakukan. Materi-materi perkuliahan yang diberikan pada Progam Studi PAI selain ilmu-ilmu keagamaan juga ilmu-ilmu umum, khususnya yang terkait dengan psikologi dan metodologi pengajaran. Karenanya, kedeua keilmua tersebut harus disandingkan untuk dapat menghasilkan calon-calon guru yang selain mengusai materi agama Islam dengan baik, juga menguasai cara menyampaikan materi tersebut dalam kelas pembelajaran. Tulisan ini menggambarkan bahwa secara ontologi, epistilomoli dan aksiologi bangunan keilmuan PAI sangat kokoh, sehingga tetap dapat dipertahanan menjadi satu bangunan keilmuan.

Kata kunci: Prodi Pendidikan Agama Islam, ontologi, epistimologi, dan aksiologi

\section{Pendahuluan}

Kehadiran lembaga pendidikan Islam di Indonesia merupakan wujud dari kesadaran, sikap patriotism, dan rasa nasionalisme serta sebagai respon tokoh-tokoh Islam terhadap berbagai kondisi uamt Islam yang mengalami 
kemunduran akibat dari penjajahan Belanda ${ }^{1}$.

Tanpa kehadiran lembaga pendidikan Islam, seperti pondok pesantren, madrasah, dan perguruan tinggi keagamaan Islam, agama Islam sudah lama lenyap dari bumi Indonesia ${ }^{2}$.

Perguruan Tinggi Keagamaan Islam (PTKI) baik negeri maupun swasta sebagian besar memiliki program studi Pendidikan Agama Islam $(\mathrm{PAI})^{3}$. Dalam perkembangannya, Prodi Pendidikan Agama Islam tidak hanya mengajarkan ilmu agama Islam (an sich) seperti hadits, fiqh, ushul fiqh, tafsir, dan sebagainya. Namun, juga mempelajari teori-teori tentang psikologi yang, sebagian besar berasal dari pemikiran sarjana Barat, seperti mata kuliah Ilmu Jiwa Belajar, Bimbingan dan Konseling, Ilmu Jiwa Perkembangan, Kesehatan Mental, dan sejenisnya.

Kondisi itu menimbulkan pertanyaan besar khususnya terkait dengan bangunan keilmuan PAI terutama jika dikaitkan dengan peran sentral pendidikan Agama Islam dalam membangun pondasi Agama Islam. Karenanya tulisan ini, berusaha untuk menjelaskan bangunan keilmuan Prodi Pendidikan Islam sebagai bagian dari perkembangan ilmu pengetahuan khususnya dalam bidang pendidikan.

Pembahasan dalam tulisan ini banyak menggunakan data-data yang bersifat kualitatif ${ }^{4}$, khususnya data-data yang diambil dari perpusatkaan dan diperkuat dengan dan pengamatan-bahkan pengamatan dalam praktekpraktek dalam pengelolaan Progam Studi Pendidikan Agama Islam.

\section{Sepintas tentang Pendidikan Agama Islam}

Terkait dengan pendidikan Agama Islam, ada banyak ragam pengertian yang diberikan. Zarkowi Soejoeti, memberi tiga macam pengertian

${ }^{1}$ Hasbullah, Sejarah Pendidikan Islam di Indonesia; Lintasan Sejarah Pertumbuhan dan Perkembangan. Jakarta, PT Raja Grafindo Persada, 1999 h. 91

${ }^{2}$ Mudjahid, M, Sc, Komentar Ahli dalam Seminar Hasil Penelitian Tenmtang Pendidikan Islam Pasca Reformasi yang diselenggarakan Balai Litbang Keagamaan DKI Jakarta, di Hotel Bumi Wiyata, Depok,

${ }^{3}$ Data Kementerian Ristek Dikti, yang dilacak melalui Forlaf PDDIKTI, jumlah Prodi Pendidikan Agama Islam sebanyak 562 baik yang dieselanggarakan oleh PTKIN, PTKIS, FAI dan IKIP yang berubah menjadi universutas. Dirjen Pendidikan Islam Kementerian Agama RI memoratorium pembukaan Prodi Pendidikan Agama Islam. Prodi ini sudah jenuh dan overload, salah satu alasannya.

${ }^{4}$ Lexy J Moleong, Metodelogi Penelitian Kualitatif. Bandung: PT Remaja Rosdakarya, 2006, h. 9. Bandingkan dengan Masri Singarimbun dan Sofian Effendi, Metode Penelitian Survai. Jakarta: LP3ES, 1989, h. 22 
pendidikan (agama) Islam Pertama, lembaga pendidikan itu pendirian dan penyelenggaraannya didorong oleh hasrat mengejawantahkan nilai - nilai Islam yang tercermin dalam nama lembaga pendidikan itu dan kegiatan yang diselenggarakan ${ }^{5}$. Dalam pengertian ini, Islam dilihat sebagai sumber nilai yang harus diwujudkan dalam kehidupan lembaga pendidikan yang bersangkutan.

Kedua, lembaga pendidikan yang memberikan perhatian dan menyelenggarakan kajian tentang Islam yang tercermin dalam program kajian sebagai ilmu dan diperlukan seperti ilmu - ilmu lain yang menjadi program kajian lembaga Islam yang bersangkutan. Ketiga, mengandung kedua pengertian di atas, dalam arti lembaga tersebut memperlakukan Islam sebagai sumber nilai bagi sikap dan tingkah laku yang harus tercermin dalam penyelenggaraannya maupun sebagai bidang kajian yang tercermin dalam program kajiannya ${ }^{6}$.

M. Yusuf al-Qardhawi memberikan pengertian bahwa pendidikan Islam adalah pendidikan manusia seutuhnya (akal dan hatinya, rohani dan jasmaninya, akhlak dan keterampilannya). Pendidikan Islam menyiapkan manusia untuk hidup, baik dalam keadaan damai maupun perang, dan menyiapkannya untuk menghadapi masyarakat dengan segala kebaikan dan kejahatannya, manis dan pahitnya ${ }^{7}$.

Pendidikan Islam dapat dirumuskan sebagai proses bimbingan (pimpinan, tuntutan, usulan) oleh subyek didik terhadap perkembangan jiwa (pikiran, perasaan, kemauan, intusi, dan sebagainya), dan raga obyek didik dengan bahan-bahan materi tertentu, pada jangka waktu tertentu, dengan metode tertentu dan dengan alat perlengkapan yang ada ke arah terciptanya pribadi tertentu disertai dengan evaluasi sesuai ajaran Islam. ${ }^{8}$

Pendidikan dalam Islam merupakan sebuah rangkaian proses pemberdayaan manusia menuju taklif [kedewasaan], baik secara akal, mental maupun moral, untuk menjalankan fungsi kemanusiaan yang diemban-sebagai seorang hamba $[a b d]$ dihadapan Khaliq-nya dan sebagai

${ }^{5}$ Azyumardi Azra, Pendidikan Islam: Tradisi dan Modernisasi Menuju Milenium Baru. Jakarta: Logos Wacana Ilmu, 2000, h. 24

${ }^{6}$ A Malik Fadjar, Reoreintasi Pendidikan Islam, Jakarta: Fajar Dunia, 1999, h. 31

${ }^{7}$ M Yusuf al - Qardhawy, Pendidikan Islam dan Madrasah Hasan Al Bana, terj. Prof. Bustami A. Gani dan Drs. Zainal Abidin Ahmad. Jakarta: Bulan Bintang, 1980, h.157

${ }^{8}$ Endang S Anshari, Pokok - Pokok Pikiran tentang Islam. Jakarta: Usaha Interprise, 1976, h. 85 
"pemelihara" [khalifah] pada semesta."

Pendidikan (agama) Islam mengacu pada term at tarbiyah, al ta'dib, dan at talim. Namun, dalam konteks ini, hanya dibatasi at tarbiyah. At Tarbiyah berasal dari kata Rabb. Kata ini mempunyai banyak arti, makna yang sering digunakan menunjuk pada tumbuh, berkembang, memelihara, merawat, mengatur, dan menjaga kelestarian atas eksistensinya.

\section{Landasan dan Tujuan Pendidikan Agama Islam}

Landasan pendidikan (Agama) Islam bersumber Al Quran. Walaupun mukzijat Rasulullah SAW tidak secara eksplisit menyebut profesi guru atau ustadz, namun secara implisit Kitab Suci ini menyebut tentang transfer ilmu pengetahuan sebagaimanana QS. Al Baqarah/2: 31 dan 151, Ali Imran/3: 164, Al Jumu'ah: 12, Ar Rahmaan/55: 2, dan kisah Lukmanul Hakim ketika memberi pelajaran kepada putranya, sebagaimana dalam QS. Al Luqman/31: 12 - 19.

Selanjutnya, Hadits Rasulullah SAW, Artinya: "Berkata Mu'ammal ibn Hisyam Yảni al Asykuri, berkata Ismail dari Abi Hamzah, berkata Abu Dawnd dan dia adalah sawwaru ibn Dawud Abu Hamzah Al Muzanni Al Shoirofi dari Amru ibn Syu'aib dari ayahnya dari kakeknya berkata, berkata Rasulullah SAW: Surublah anakmu melakukan sholat ketika berumur tujuh tahun. Dan pukullah mereka karena mereka meninggalkan sholat ketika berumur sepuluh tahun. Dan pisahlah mereka (anak laki-laki dan perempuan) dari tempat tidur. ${ }^{10 "}$ Selanjutnya hadits, "Didiklah putra putri kamu sekalian sesuai dengan zamannya." Selain itu, ada hadis yang menekankan pendidikan keterampilan, "Ketahuilah bahwa kekuatan adalah panahan, ketahuilah bahwa kekuatan adalah panahan, ketahuilah bahwa kekuatan adalah panahan." (HR. Muslim). Hadits - hadis tersebut, selain mengajarkan tentang ketaqwaan kepada Allah, juga umat Islam harus belanjar keterampilan hidup (life skill).

Landasan lain berupa praktek-praktek para sahabat dan khalifah baik pada masa khalifah Bani Umayyah, Bani Abassiyah, maupun khalifah kecil lainnya. Para penguasa Islam tersebut mengembangkan pendidikan Islam

\footnotetext{
${ }^{9}$ Ahmad Tafsir, Ilmu Pendidikan dalam Perspektif Islam. Bandung: Rosdakarya, 1992, h. 23

${ }^{10}$ Abu Dawud, Sunan Abu Dawud. Beirut: Al Maktabah As Syamilah, tt. Bab Al Shalat. Hadits No 412
} 
sesuai dengan metode dan materi yang berkembang pada saat itu. ${ }^{11}$.

Yang tak kalah penting adalah seperangkat peraturan perundanganundangan tentang pendidikan yang dilahirkan sejak zaman reformasi sampai sekarang. Seperti Undang-Undang No 20 Tahun 2003 tentang Sisdiknas Bab II Pasal 3, "Pendidikan Nasional berfungsi mengembangkan kemampuan dan membentuk watak dalam rangka mencerdaskan kehidupan bangsa, bertujuan untuk mengembangkan potensi peserta didik agar menjadi manusia yang beriman dan bertakwa kepada Tuhan Yang Maha Esa, berakhlak mulia, sehat, berilmu, cakap, kreatif, mandiri, dan menjadi warga Negara yang demokratis serta bertanggung jawab ${ }^{12}$." Serta UU No 14 Tahun 2005 tentang Guru dan Dosen, UU No 12 tahun 2012 tentang Perguruan Tinggi, dan peraturan perundang-undangan terkait lainnya.

Beranjak dari 6 (enam) landasan tersebut, Nurcholis Madjid, sebagaimana dikutip A Malik Fadjar, berpendapat bahwa pendidikan (agama) Islam memiliki dua dimensi hidup yaitu dimensi ketuhanan dan kemanusiaan. Dimensi ketuhanan untuk memupuk rasa ketaqwaan kepada Allah SWT sebagai Rabb, pemilik seluruh alam. Dimensi kemanusiaan dalam arti bahwa dalam pendidikan Islam bukan hanya mengusai pengetahuan agama secara kognitif, akan tetapi seberapa jauh pengetahuan agama tersebut tertanam dalam peserta didik. Sehingga aspek afektif tersebut mewarnai kehidupan peserta didik sehari-hari. ${ }^{13}$

Tujuan tersebut secara umum sesuai dengan tujuan pendidikan (agama) Islam sebagaimana diungkapkan oleh para ahli pendidikan Islam. Seperti M Arifin, ${ }^{14}$ Syaibany, ${ }^{15}$ Langgulung, ${ }^{16}$ dan Al Abrasy. ${ }^{17}$ Al Abrasyi berpendapat tujuan pendidikan (agama) Islam memiliki lima tujuan: (1) membentuk akhlak mulia; (2) mempersiapkan kehidupan di dunia dan akherat; (3) persiapan mencari rizki dan memelihara kemanfaatannya; (4) menumbuhkan semangat ilmiah di kalangan peserta didik; dan (5)

\footnotetext{
${ }^{11}$ M Sjalabi , Sejarah Pendidikan Islam. Djakarta, PT Bulan Bintang, 1973

${ }^{12}$ Anwar Arifin, Memahami Paradigma Baru Pendidikan Nasional dalam Undang - Undang Sisdiknas. Jakarta: Ditjen Kelembagaan Agama Islam Kementerian Agama RI, 2003, h. 31

${ }^{13}$ A Malik Fadjar, Loc. Cit,, h. 7 - 23

${ }^{14}$ M Arifin. Filsafat Pendidikan Islam. Jakarta: Bina Aksara, 1987, h. 120

15 Omar Muhammad at Thoumy Al Syaibany, Falsafah Pendidikan Islam. Jakarta: Bulan Bintang, 1979, h. 410

${ }^{16}$ Hasan Langgulung, 1989, h. 35

${ }^{17}$ Al Abrasy, 1984, h. 1-4
} 
mempersiapkan tenaga profesional yang terampil.

Yang perlu diingat adalah tujuan Pendidikan Agama Islam yang dirumuskan saat Kongres Pendidikan Islam Se-Dunia Ke-2 tahun 1980 di Islamabad, Pakistan, sebagaimana dikutip Hasan Langgulung, ${ }^{18}$

"Untuk mencapai keseimbangan pertumbuhan kepribadian manusia secara menyeluruh dan seimbang yang dilakukan melalui latihan jiwa, akal pikiran (intelektual), diri manusia yang rasional; perasaaan dan indera. Karena itu, pendidikan hendaknya mencakup pengembangan seluruh aspek fitrah peserta didik; aspek spiritual, intelektual, imajinasi, fisik, ilmiah, dan bahasa, baik secara individual dan kolektif; dan mendorong semua aspek tersebut berkembang ke arah kebaikan dan kesempurnaan. Tujuan akhir pendidikan muslim terletak pada perwujudan ketundukan yang sempurna kepada Allah, baik secara pribadi, komunitas, maupun seluruh umat manusia."

Tujuan Prodi Pendidikan Agama Islam pun, selaras dengan deklarasi UNESCO tentang perguruan tinggi. Menurut Azyumardi Azra, pertama, memberikan kontribusi kepada pembangunan yang berkelanjutan; kedua, memberikan berbagai kesempatan kepada warga negara untuk memperoleh pendidikan tinggi sepanjang usia; ketiga, memajukan, menciptakan, dan menyebarkan ilmu pengetahuan melalui riset; keempat, membantu untuk memahami, menafsirkan, memelihara, memperkuat, mengembangkan, dan menyebarluaskan budaya historis nasional, regional, dan international dalam pluralisme dan keragaman budaya; kelima, membentuk watak dan nilai-nilai demokratis; dan keenam, memberikan kontribusi kepada pengembangan dan peningkatan pendidikan pada seluruh jenjangnya termasuk pelatihan para guru. ${ }^{19}$

\section{Bangunan Ilmu Prodi Pendidikan Agama Islam}

Prodi Pendidikan Agama Islam harus memiliki bangunan keilmuan (body of knowledge) yang dapat dipertanggungjawabkan kebenaran sesuai metode ilmiah. Dengan kata lain, semua mata kuliah yang diajarkan pada

\footnotetext{
${ }^{18}$ Hasan Langgulung, Loc Cit, h. $206-7$

${ }^{19}$ Komarudin Hidayat dan Hendro Prasetyo Ed. Problem dan Prospek IAIN Antologi Pendidikan Tinggi Islam. Jakarta: Direktorat Pembinaan Perguruan Tinggi Agama Islam Direktorat Jenderal Pembinaan Kelembagaan Agama Islam Departemen Agama RI, 2000), h. 7 - 9
} 
jurusan tersebut mempunyai struktur kurikulum, materi, syllabus, bahan ajar dan metodologi pengajaran, termasuk juga alokasi waktu perkuliahan dan ruang belajar.

Secara ontologis, ${ }^{20}$ Prodi PAI tidak men-dikotomi-kan ilmu agama dan ilmu umum, profan dan sekuler, dunia dan akherat; karena semua ilmu bersumber dari Zat Yang Maha Berilmu, yang tak lain Tuhan, Allah Swt. sendiri. Jika ilmu agama bersumber pada ayat-ayat tadwini; ilmu sekuler/ umum bersumber pada kauni. ${ }^{21}$ Apabila yang pertama menggunakan metode bayani, burhani, dan irfani; maka yang kedua menggunakan metode induktif dan deduktif dengan cara pengamatan/ obervasi. ${ }^{22}$

Semangat Konferensi Pendidikan Islam se- Dunia di Mekkah 1977, menegaskan bahwa ilmu agama dan ilmu umum merupakan satu: Karena hakehatnya keduanya berasal dari Allah. Oleh karena itu, dalam pandangan yang dikhotomi ini kedua ilmu disatukan : ilmu yang berasal dari Allah (ilmu abadi: Ilahi) menjadi asas atau dasar ilmu yang berasal dari otak manusia (ilmu pencapaian, penalaran, intelektual: insani. ${ }^{23}$

Kesimpulan yang diambil oleh Mohammad Daud Ali tersebut merupakan elobarasi dari klasifikasi ilmu yang dibuat oleh Al Farabi $(258 \mathrm{H}$ - 339H/870 M - $950 \mathrm{M})$, Al Gazali (450 H - $505 \mathrm{H} / 1058 \mathrm{M}-1111 \mathrm{M})$, dan Quthubuddin al Syirazi $(634 \mathrm{H}-710 \mathrm{H} / 1256 \mathrm{M}-1311 \mathrm{M}) .^{24}$

Menurut pandangan filsuf Barat, ilmu agama, termasuk PAI, bukan bagian ilmu pengetahuan. Alasannya, sebuah ilmu (pengetahuan) harus diobservasi, dapat diverifikasi kebenarannya melalui berbagai pengujian, dan bersifat empiris. Sebagaimana pendapat David Hume, Bertrand Russell, Emmanuel Kant, karena ilmu agama (Islam) tidak empiris, tidak skeptic, tidak induktif, dan tidak deduktif. ${ }^{25}$ Sementara ilmu agama (Islam), kebenarannya merupakan taken for granted (sesuatu yang sudah terjadi).

${ }^{20}$ Dalam penelitian ini, peneliti mengambil konsep ontologis, epistomologis, dan aksiologis dari Prof Dr C.A. van Peursen, dalam buku Strategi Kebudayaan. Alih bahasa Dick Hartoko. Yogjakarta: Penerbit Kanisius, 1992

${ }^{21}$ Mulyadhi Kartanegara, Loc Cit, hal, 22

${ }^{22}$ Jujun S Suriasumantri , Ilmu dalam Perspektif:: Sebuah Kumpulan Karangan tentang Hakehat Ilmu. Jakarta: Gramedia, 1978, hal, $43-45$

${ }^{23}$ Mohammad Daud Ali, Pendidikan Agama Islam. Jakarta: RajaGrafindo Persada 2006, h. 393

${ }^{24}$ Osman Bakar, Hierarki Ilmu Menurut Al Farabi, Al Gazali, Quth al Din al Syirazi. Bandung: Mizan, 2006

${ }^{25}$ Untuk mendalami masalah ini buku membacara buku Bakker, Anton, Metode - Metode Filsafat. Jakarta: Ghalia Indonesia, 1982 dan buku Jujun S Suriasumatri, op cit 
Walaupun ada ilmu-ilmu agama yang bersifat interpreratif dan ijtihadi

Sebagai misal, materi perkuliahan Pendidikan Agama Islam mulai dari Al-Quran, hadits, fiqh, tauhid, tafsir, akhlak, dan seterusnya tidak berubah sejak awal materi tersebut dikodifikasi, diajarkan, dikembangkan sampai sekarang. Mulai dari bersuci dengan teknologi sampai menjalankan ibadah mahdhah dari zaman Rasulullah sampai sekarang tidak mengalami perubahan. Demikian pula, materi kurikulum PAI mulai dari pelajaran fiqh, akhlak, tauhid/akidah, sejarah kebudayaan Islam pun tidak berubah. Hanya metodelogi dan strategi belajar-mengajar yang berkembang sesuai dengan tren teknologi dan perkembangan zaman.

Untuk mata kuliah tafsir, yang berubah adalah metode penafsiran ayat Al Qur'an. Sebagai misal, dalam ilmu tafsir, telah berkembang tafsir Al Qur'an dengan metode hermeneuti ${ }^{26}$ yang mulai digandrungi kalangan Islam progresif ${ }^{27}$ namun metode ini belum diajarkan di bangku-bangku perkuliahan tafsir al-Qur'an pada Prodi Pendidikan Agama Islam fakultas Tarbiyah pada perguruan tinggi keagamaaan Islam swasta.

Mata kuliah tafsir yang diajarkan pada fakultas lingkup PTKIN dan PTKIS adalah metode ijmali, tahlili, muqaran, dan maudhui. Sebagaimana Quraisy Syihab menggunakan metode maudhui (tematik) dalam tafsir Membumikan Al-Quran ${ }^{28}$ dan Al Misbah. ${ }^{29}$ Sementara penafsiran Al Quran dengan metode hermeneutik dikecam habis-habisan karena dianggap menyimpang dari tradisi Rasulullah SAW, para sahabat dan para ulama ahli tafsir salafus shaleh. Tafsir dengan metode hermeneutic dipengaruhi oleh pemikiran Barat yang liberal; ayat-ayat Al Quran tidak ada bedanya dengan teks-teks buku biasa. ${ }^{30}$

Prodi Pendidikan Agama Islam, selain menyebarkan kebenaran absolut tentang ilmu pengetahuan keagamaan, juga melakukan penelitian yang berkaitan dengan dunia pendidikan. Dalam penelitian ini, ingin mencari 'kebenaran' relative yang hidup dalam masyarakat Indonesia. Berpijak dari sini, maka Prodi PAI memanfaatkan berbagai teori tentang kebenaran.

\footnotetext{
${ }^{26}$ Muhammad Shahrur, Tashwirul Afkar Edisi No 16 Tahun 2004

${ }^{27}$ Muhammad Shahrur, Tashwirul Afkar Edisi No 16 Tahun 2004

${ }^{28}$ M Quraisy Shihab, Membumikan Al Quran. Bandung : Mizan, 1986

${ }^{29}$ M Quraisy Shihab, Al Misbah. Jakarta: Lentera Hati, 2014

${ }^{30}$ Adian Husaini dan Abdurrahman al Baghdadi, Hermeneutika Tafsir Al Qur'an Jakarta: Gema Insani Press, 2004, hal, 4 - 5
} 
Dalam dunia ilmiah, teori kebenaran berangkat dari tiga hal: Pertama, teori korespondensi (pertautan dengan fakta); kedua, koherensi (teori tengang koherensi); dan ketiga, pragmatis (tentang kemanfaatan). ${ }^{31}$

Sementara, untuk memperoleh kebenaran, Ali Syariati, menegaskan bahwa penggunaan metode ilmiah tidaklah tunggal dari sekian banyak metode yang berkembang dewasa ini. Karena Islam bukan agama satu dimensi (uni dimensional). Untuk mempelajari Islam yang banyak dimensinya itu, selain dengan memanfaatkan metode filosofis, pun harus menggunakan metodemetode yang terdapat dalam ilmu manusia dewasa ini. ${ }^{32}$

Terlepas dari perdebatan tersebut, kemudian merujuk dari pemahaman yang disampaikan Kartanegara di atas, maka mata kuliah yang diajarkan pada fakultas Tarbiyah Prodi PAI tradisi keilmuan dari pemikir Islam diintegrasikan dengan tradisi keilmuan dari pemikiran filosuf Barat. Dalam pengajaran materi kuliah Ilmu Jiwa, misalnya, selain menyajikan pemikiranpemikiran dari ahli ilmu jiwa seperti Sigmun Freud dengan psiko analisa, yaitu ego dan aid, ${ }^{33}$ serta Abraham Maslow dengan teori motivasinya, ${ }^{34}$ melainkan juga mengeksplorasi pemikiran filsuf Islam seperti Al Kindi, Al Razi, Al Farabi, Ibn Sina, Al Ghazali, dan filsuf muslim lainnya, yang fasih bicara soal rohani (jiwa) manusia. Sehingga kurikulum Ilmu Jiwa Belajar, Psikologi Pendidikan, Bimbingan dan Konseling, dan sejenisnya pada PS PAI semakin kuat dan kukuh pijakan basis epistimologi.

Sebagai perguruan tinggi tinggi agama Islam, bukan hanya bersandar sebagai nilai-nilai Ilahiyah ( tazkiyatun nufus), akan tetapi senantiasa menempatkan Al-Quran dan Hadis sebagai sumber ilmu pengetahuan. Maka mata kuliah - mata kuliah yang diajarkan pada Prodi PAI harus mengeksplorasi kedua sumber tersebut. Dengan demikian, Prodi PAI bukan hanya sinerg-integrasi-koneksi meminjam istilah M. Amin Abdullah atau integrasi ilmu meminjam Mulyadhi Kartanagera—antara mata kuliah keagamaan, kemudian dicangkokkan dengan mata kuliah ilmu umum. ${ }^{35}$

${ }^{31}$ Harold Titus dkk, Persoalan-Persoalan Filsafat, alih bahasa M Rasjidi. Jakarta: Bulan Bintang, 1984, h. $237-244$

${ }^{32}$ Ali Syariati, On The Sociology of Islam. Berkeley: Mizan Press, 1979, h. 72

${ }^{33}$ Sigmund Freud, The Ego dan The Id. New York: Norton, 1962.

${ }^{34}$ Abraham Maslow H, Motivation and Personality. New York: Harper, 1945. Secara garis besar dia membagi motivasi menjadi lima fisiologi, rasa aman, afiliasi, harga diri, dan aktualisasi diri. Kemudian bandingkan dengan hadits ikhlas beramal: Innamal ämalu bin niyat...

${ }^{35}$ Kecenderungan seperti ini munculnya PS Perbankan Islam, PS Perbankan Syariat, PS 
Melainkan, Prodi PAI merupakan penerapan ajaran nilai-nilai Islam sebagai dasar Ilmu Pengetahuan. ${ }^{36}$

Secara aksiologis, Prodi PAI harus mampu menjawab persoalan-persoalan praksis yang berkembang di masyarakat. Sehingga materi perkuliahan pada jurusan ini harus memiliki perspektif masyarakat yang majemuk (plural), multikultural, dan HAM. Prodi Pendidikan Agama Islam harus mampu memberi solusi dan pencerahan bagaimana hubungan antara materi PAI dengan, misalnya, yang diajarkan dalam sekolah-sekolah umum.

Metode-metode pengajarannya pun lebih banyak menggunakan androgogi dan emansipatoris daripada menggunakan metode indoktrinatif dan dogmatis. Out come yang diharapkan, masyarakat Jakarta dan sekitarnya yang multi kompleks akan memiliki guru agama, ustadz, guru ngaji, atau apalah sebutannya yang memiliki kompetensi ilmu (PAI) sesuai karakter masyarakat yang pluralis dan multilkulturalis, ${ }^{37}$ akan tetapi bukan dalam arti isme.

Dalam konteks lebih luas, Prodi Pendidikan Agama Islam dapat mengembangkan masyarakat belajar yang kreatif, mandiri terbuka (open mindend), demokratis, inkuiri, dan efektif. Sebab kecenderungan utama masa depan adalah adanya perubahan yang cepat (increasingly rate of change) yang mengakibatkan ketidakpastian, di samping kepastian-kepastian yang didasarkan fakta sosial-budaya yang berkembang. ${ }^{38}$

\section{Penutup}

Dari kajian diatas, bahwa Prodi Pendidikan Agama Islam memiliki landasan yang keilmuan kokoh, baik dilihat dari ontologis, etimologis, maupun aksiologis. Selain mengembangkan ilmu yang bersumber pada $\mathrm{Al}$ Quran dan Hadits, juga teori-teori keilmuan baik kajian ilmu pendidikan maupun kajian ilmu lainnya.

Oleh karena itu, Prodi Pendidikan Agama Islam dapat menjadi pijakan

\footnotetext{
Akuntansi Islam dan sejenisnya. Pencangkokan ini disebabkan basis keilmuannya atau ontology dan epistimologi-nya tidak kokoh. Atau dalam kata lain PS - PS tersebut sedang mencari formula keilmuan yang pas.

${ }^{36}$ Baca QS Al Muluk /67: 26

${ }^{37}$ Baca hasil penelitian Balai Litbang Agama Jakarta dalam bahasan ini. Akhmad Syafei, dkk. Pendidikan Agama Islam dalam Perspektif Multikulturalisme. Jakarta: Balai Litbang Agama Jakarta, 2009

${ }^{38}$ Syafrudin dan Irwan Nasution, Manajemen Pembelajaran. Jakarta: Ciputat Press, 2005, h. 19
} 
dalam mengelola sebuah pembelajaran yang sistematis, terorganisasi, dan terukur lewat berbagai kegiatan baik penguasaan kurikulum, perancanaan pembelajaran, dan seterusnya yang, semuanya itu diajarkan oleh fakultas Tarbiyah Prodi Pendidikan Agama Islam, terangkum dalam bentuk silabus, bahan ajar, dan SAP serta dalam bentuk penelitian dan pengabdian kepada masyarakat.

\section{Pustaka Acuan}

Abdullah, M Amin, Islamic Studies di Perguruan Pendekatan Integratif Interkonektif. Yogjakarta: Pustaka Pelajar, 2006.

Arifin, Anwar, Memahami Paradigma Baru Pendidikan Nasional dalam Undang-Undang Sisdiknas. Jakarta: Ditjen Kelembagaan Agama Islam Kementerian Agama RI, 2003

Azra, Azumardi, Pendidikan Islam: Tradisi dan Modernisasi Menuju Milenium Baru. Jakarta: Logos Wacana Ilmu, 2000.

Anshari, Endang Saefuddin, Pokok-Pokok Pikiran tentang Islam. Jakarta: Usaha Interprise, 1976

Ali, Mohammad Daud, Pendidikan Agama Islam. Jakarta: RajaGrafindo Persada, 2006

Arifin, M., Filsafat Pendidikan Islam. Jakarta: Bina Aksara, 1987

Bakker, Anton, Metode-Metode Filsafat. Jakarta: Ghalia Indonesia, 1982

Bakar, Osman, Hierarki Ilmu Menurut Al Farabi, Al Gazali, Quth al Din al Syirazi. Bandung: Mizan, 2006

Buchori, Mochtar, dkk., Reorientasi Ilmu Pendidikan di Indonesia. Jakarta: IKIP Muhammadiyah Jakarta Press, 1995

Dawud, Abu, Sunan Abu Dawud. Beirut: Al Maktabah As Syamilah, tt Fadjar, A. Malik, Reorentasi Pendidikan Islam. Jakarta: Fajar Dunia, 1999 Freud, Sigmund, The Ego and The Id. New York : Norton, 1962 Hasbullah, Sejarah Pendidikan Islam di Indonesia; Lintasan Sejarah Pertumbuhan dan perkembangan. Jakarta, PT Raja Grafindo Persada, 1999

Hidayat, Komaruddin dan Hendro Prasetyo (Ed.), Problem dan Prospek IAIN Antologi Pendidikan Tinggi Islam. Jakarta: Direktorat Pembinaan Perguruan Tinggi Agama Islam Direktorat Jenderal Pembinaan Kelembagaan Agama Islam Departemen Agama RI, 2000

Husaini, Adian dan Abdurrahman al Baghdadi, Hermeneutika Tafsir Al Qur'an. Jakarta: Gema Insani Press, 2004 
Kartanegara, Mulyadhi, Integrasi Ilmu Sebuah Rekonstruksi Holistik.

Bandung: Arasy Mizan, 2003

Langgulung, Hasan, Manusia dan Pendidikan: Suatu Analisa Psikologi dan Pendidikan. Jakarta: Pustaka Al Husna, 1989

Maslow H, Abraham, Motivation and Personality. New York: Harper, 1945

Moleong, Lexy J., Metodelogi Penelitian Kualitatif. Bandung: PT Remaja Rosdakarya, 2006

Nahlawi, Abdurrahman, Prinsip-Prinsip dan Metode Pendidikan Islam. Bandung: CV Diponegoro, 1992

Noer, Deliar, Gerakan Modern Islam Indonesia 1900-1942. Jakarta: LP3ES, 1984

Nolan, Smite, dan Titus dkk, Persoalan-Persoalan Filsafat, penerjemah HM Rasjidi. Jakarta: PT Bulan Bintang, 1984

Perebutan Identitas Islam Pergulatan Islamisme dan Islam Progresif, Tashwirul

Afkar Jurnal Refleksi Pemikiran Keagamaan \& Kebudayaan, Edisi No 16 Tahun 2004

Qardawy, Yusuf Al, Pendidikan Islam dan Madrasah Hasan Al Bana, terj.

Prof. Bustami A. Gani dan Drs. Zainal Abidin Ahmad. Jakarta: Bulan Bintang, 1980

Sjalabi, Achmad, Sejarah Pendidikan Islam. Djakarta, PT Bulan Bintang, 1973

Shihab, Quraisy, Membumikan Al Quran. Bandung: Mizan, 1987 Tafsir Al Misbah. Jakarta: Lentera Hati, 2009

Singarimbun, Masri dan Sofian Effendi (Ed.), Metode Penelitian Survai. Jakarta: LP3ES, 1989

Syafrudin dan Irwan Nasution, Manajemen Pembelajaran Jakarta: Ciputat Press, 2005

Syariati, Ali, On The Sociology of Islam. Berkeley: Mizan Press, 1997

Syafei, Akhmad, dkk. Pendidikan Agama Islam dalam Perspektif Multikulturalisme. Jakarta: Balai Litbang Agama Jakarta, 2009

Syaibany, Omar Muhammad at Thoumy Al, Falsafah Pendidikan Islam. Jakarta: Bulan Bintang, 1979

Suriasumantri, Jujun S., Ilmu dalam Perspektif: Sebuah Kumpulan Karangan tentang Hakehat Ilmu. Jakarta: PT Gramedia, 1978

UU No 20 tahun 2004 tentang Sistem Pendidikan Nasional

UU No 14 tahun 2005 tentang Guru dan Dosen

UU No 12 tahun 2012 tentang Perguruan Tinggi 